\title{
THE IMPLEMENTATION OF THE CASE ASSIGNMENT METHOD OF PATIENT CARE AT THE DR. A.J. STALS CARE AND REHABILITATION CENTRE
}

\author{
Nora L. Daniels \\ Principal Matron \\ Dr. A.J. Stals Care and Rehabilitation Centre
}

\section{OPSOMMING}

Die moderne benadering tot die versorging van die geestesvertraagde in inrigtings is nie slegs meer om selfhulpvaardighede te voorsien nie, maar om elke pasiënt op te lei en te rehabiliteer om hom sodoende in staat te stel om tot sy maksimum potensiaal te funksioneer.

Dit vereis dat elke inwoner se vermoëns vasgestel en 'n program vir sy opleiding na aanleiding van sy behoeftes en bekwaamhede opgestel moet word.

Inwoners wat dieselfde opleidingsprogramme vereis word saam onder toesig van 'n verpleegster groepeer. Die aantal inwoners in een groep word deur hul selfhulpvaardighede bepaal.

Die ingeskrewe verpleegassistent, onder toesig van die saalsuster en onder leiding van die multidissiplinêre span, kan verantwoordelikheid vir die uitvoering van die opleidingsprogramme aanvaar.

\section{Introduction}

$\mathbf{T}_{\mathrm{r}}$ he modern approach to the care of the mentally retarded in institutional settings is no longer to provide only custiodial care, but to train and rehabilitate each patient to be able to function at his maximal potential. This requires that each resident must have his abilities assessed and a programme implemented for his training, according to his particular needs and capabilities. Residents requiring similar training programmes are therefore grouped together under the care of one nurse, the number of residents in each group depending upon their selfcare skills. The nurse is assigned the responsibility of carrying out the training programme under the supervision of the Ward Sister and with the guidance of the multidisciplinary team under the leadership of the psychiatrist.

\section{The Value of the Case Assignment Method}

2.1 The nursing process is more easily facilitated when the nurse stays with her group of patients long enough for her personally to determine their problems, plan to solve them, initiate these plans and evaluate the extent to which the plan was effective.

2.2 The mentally retarded person needs to be able to form a permanent trusting relationship with one or more persons. Acting out frequently occurs as a result of constant staff changes.
2.3 Residents develop a feeling of group-cohesion in small family-like groups.

2.4 By grouping patients together who have the same needs, organisation is simplified.

2.5 Residents may aspire to be promoted to a higher category group.

3. Defining the Problems Associated with the care of the Severely and Profoundly Retarded

3.1 Outlining the Roles and Functions of Nursing Personnel

The care and rehabilitation of mentally retarded persons requires the skills of many disciplines, and questions have been asked, by the Jay Committee ${ }^{2}$, for instance, whether in fact this type of care should be administered by the nursing profession. The skills of the following disciplines are needed: Occupational Therapists, Physiotherapists, Social Workers, Clinical Psychologists and Psychiatric Nurses.

The ratio of paramedical staff to patient does not allow for individual care to each patient, while the nursing staff are in close contact with the residents for 24 hours of the day. More particularly, it is the enrolled nursing assistant, under the supervision of the Ward Sister, who is the only person working closely and intimately at all times with the resident. 
The registered nursing staff therefore have to ensure that those principles of rehabilitation which are delegated to the nursing assistant are clearly understood by her.

Close co-operation and team work are essential if the paramedical staff are to make a contribution towards improving the skills and knowledge of the nursing assistant, while a clear definition of the roles and functions of team members is essential. The skills required by the nurse are those for the creation of a therapeutic environment, health education, counselling, socialising, teaching, communicating, promoting movement and preventing physical deformities and providing activity programmes. When one adds the basic technical nursing skills required, it is evident that a great deal is expected from the nursing assistant.

Virginia Henderson states (1)"the unique function of the nurse is to assist the individual, sick or well, in the performance of those activities contributing to health or its recovery (or to a peaceful death) that he would perform unaided if he had the necessary strength, will or knowledge. And to do this in such a way as to help him gain independence as rapidly as possible'".

This definition of the function of the nurse leaves little doubt that the care of the retarded is as much the responsibility of the nurse as is any other specialised branch of nursing. Provided that the multidisciplinary team is prepared to work only for the best interests of the patient, role confusion should not occur.

\subsection{Education of Nursing Personnel}

The case assignment method of care is a new concept to many of the staff working in care and rehabilitation centres, whose basic training has been in the provision of custodial care.

Education programmes have therefore to be provided for all members of staff. The team must reach unanimity on what should be taught, and how education should be given. Formal lectures are necessary, but the team has to be prepared also to work closely with the nursing staff in the ward situation, which is time consuming.

\subsection{Motivation of Nursing Personnel}

Staff have to be persuaded to become firmly committed to the normalisation principle, and to believe that all mentally retarded persons can make progress, however slow, provided that patient, consistent and repetitive teaching is exercised, and realistic goals are set.

In the functional system of caring for the retarded, a nurse does not see the results of her training pro- gramme. In the case assignment method the achievements of the resident are also the achievements of that particular group nurse, and can be used as incidents when staff reports are written by her supervising officer.

4. Stages in the Introduction of the Case Assignment Method of Rehabilitation at this Centre

\subsection{Planning}

Weekly meetings of the multi-disciplinary team were held. It was decided to use one ward as a prototype, and to include all the nursing staff of this ward at these meetings.

\subsection{Assessment of Patients}

Before programmes could be drawn up for individual groups, their capabilities had to be assessed. Because of the large number of patients this assessment had to be done by the nursing assistant, and a schedule had to be devised which could be used by her. (For evaluation chart see Annexure 'A').

The assessment charts were tested for validity and reliability for use by the nurse in the ward situation.

\subsection{Activity Programmes}

A system was worked out whereby planned and organised activities could take place in the wards. Each group nurse would collect a box from the Occupational Therapy Department each morning.

This box would contain a set of cards outlining the daily activities and the equipment necessary for these activities (for examples of the cards see Annexure ' $B$ ')

\subsection{Rehabilitation Schemes}

Each group leader would choose one patient from her group to whom she would apply intensive rehabilitation. His gross motor development would be assessed according to Annexure ' $\mathrm{C}$ '.

The tasks which he had already achieved would be noted on his record, and she would commence his training programme at a task which he had not yet achieved. She would proceed in this way until he achieved his maximal potential, and while maintaining him at this level would proceed to the next patient.

Nurses were encouraged to visit the library and consult the prescribed books themselves, so that an interest would be developed in them to do their own research. The ward doctors were requested to give guidance to them in the implementation of the scheme (see Annexure ' $C$ ') . 
The Physiotherapist worked with the nurses in the ward, instructing them on the correct manner of seating and carrying the spastic patients, doing passive movements, and teaching of feeding.

Large diagrams of these procedures were drawn and placed on the walls of the wards.

Two nurses were assigned to the Physiotherapy Department.

The skills and knowledge which they obtained there were utilised by these nurses visiting the wards and instructing the group nurses.

\subsection{Allocation of Staff to Wards}

The nurse administrators, in conjunction with the Ward Sister, ascertained how many patients a nurse could effectively care for, by observing the nurses at work.

It appeared that the ideal staff/patient ratio should be as follows:

Category A Patients : 1 Nurse to 25 Patients

Category B Patients : 1 Nurse to 12-13 Patients

Category C Patients : 1 Nurse to 8-9 Patients

Category D Patients : 1 Nurse to 5-6 Patients

The overall total required proved to be consistent with the ideal recommended ratio of 1 nurse to 3 patients.

These figures will also depend upon the physical structure of the wards, and may have to be slightly modified according to the number of patients each ward holds and the size of cubicles, side-wards or dormitories.

\subsection{Allocation of Off-Duties}

The next task was to arrange the off-duty rosters so that one nurse would remain with her group. Nursing staff work from $07 \mathrm{~h} 00$ to $18 \mathrm{~h} 00$, with an hour for lunch. Two days off duty follow every 3 days on duty. One nurse is therefore with her group for 3 days relieved by another nurse on her days off. Five nurses are required for every 3 groups. Apart from being most economical in terms of manpower utilisation, the nurses remain with their groups throughout the day, and do not have the discontinuity which would arise from 'split-shifts'.

The nursing staff allocated to a ward remain in that ward for as long as possible, with only pupil nurses and pupil nursing assistants rotating. Nurses are advised to request a change of ward should they so wish.

\section{Implementation of the Plan}

\subsection{Involvement of Ward Staff}

When the multidisciplinary team were satisfied that sufficient research had been done, the next stage was to include all the nursing staff in the implementation of the plan. In-service education was devoted to this subject to all categories of staff over a period of six weeks.

\subsection{Full-scale Assessment of Patients}

An assessment was done on all residents, and the number in each category, subdivided into age groups, was ascertained. These residents were assigned to the location most suited to their needs. The precise number of nursing staff required could then be allocated to each ward.

It was found necessary to draw up a motivation for the appointment of 40 additional nursing assistants to the establishment.

Applicants for admission are interviewed and assessed before being placed on the waiting list. They are admitted only when a bed is vacant in a suitable ward.

\section{Group Programmes}

Each group nurse is responsible for making her own programme. By staggering times for bathing and activities, overcrowding of facilities is alleviated, e.g. one group will be out walking while another is playing games and another is bathing.

\section{Each group programme must include times for:}

Meals and teas

Personal hygiene

Toilet training

Acitivity programmes, occupational or industrial therapy

Physical exercises, passive movements and music

Use of rehabilitation scheme

Provision of entertainments

Unstructured time

When a nurse leaves the ward for her own meal and tea times, two groups are cared for by one nurse.

\section{Evaluation of Progress}

The multidisciplinary team visits a ward each week. The grouping of patients is discussed, and each nurse is encouraged to talk about her programme and progress made by individual patients.

If a resident is re-assessed and found to have improved he is placed in a higher category in a different group. 
There are still problems, which will continue until a full establishment of staff is reached and until all the staff become totally familiarised with the scheme. With the training of pupil nurses in the mental retardation elective course, and the appointment of the additional nursing assistants requested, it is envisaged that the scheme should be running smoothly within a year.

\section{CONCLUSION:}

All members of staff at this Centre approached this project with enthusiasm and interest. Without the Clinical Psychologists to make the Assessment Chart, the Occupational Therapists to make the Activity Charts, the contributions of the Physiotherapist and the Medical Staff, the co-operation of the Nursing Staff and the guidance and leadership of the Medical Superintendent, success would not have been achieved.

\section{PASIËNTE-EVALUERING : "ANNEXURE" 'A'}

$\mathbf{A}=$ Pasiënte wat tot selfversorging, sosialisering, kommunikasie en beroepsvaardighede in staat is, wat in staat is om in nywerheidsterapie te werk en wat 'n program ter voorbereiding vir ontslag deurloop.

$\mathrm{B}=$ Pasiënte wat tot selfversorging in staat is, maar wat sosialisering, kommunkiasie en beroepsvaardighede moet aanleer.

$\mathrm{C}=$ Pasiënte wat hulp benodig met die basiese selfsorgvaardighede. Hulle kan deel neem aan een of ander aktiwiteit in die saal of arbeidsterapieafdeling.

$\mathrm{D}=$ Pasiënte wat oor geen van genoemde vaardighede beskik nie en $100 \%$ verpleegsorg of noukeurige toesig benodig.

\section{KRITERIA}

I. PERSOONLIKE VOORKOMS EN SELFVERSORGING

1. Is die persoon se voorkoms normaal? (Goed 2, Redelik 1, Swak 0)

2. Kan die persoon homself was? (Sonder toesig 2, Gedeeltelik 1, Glad nie 0)

3. Kan die persoon homself aantrek? (Sonder toesig 2, Gedeeltelik 1, Glad nie 0)

4. Kan die persoon self eet? (Sonder toesig 2, Gedeeltelik 1, Glad nie 0)

5. Kan die persoon self die toilet gebruik? (Sonder toesig 2, Gedeeltelik 1, Glad nie 0)

6. Het die persoon onaanvaarbare persoonlike gewoontes, bv. kwyl, in sy neus krap, klere skeur, kop $\mathrm{krap}$, in die openbaar defekeet of urineer, ens.? (Ja 0 , Nee 2)

7. Kan die persoon eenvoudige takies en opdragte uitvoer, bv. gestuur word, sy bed opmaak, vloere vee, ens? (Sonder toesig 2, Gedeeltelik 1, Glad nie 0)

8. Hoe gereeld kry die persoon epileptiese aanvalle? (Glad nie 2, Minder as 4 keer per maand 1, 4 of meer keer maand of status 0 )

\section{EMOSIONELE STABILITEIT}

1. Rand die persoon ander persone aan? (Glad nie 2, Minder as 2 keer per week 1, Meer as 2 keer per week 0)

2. Beseer die persoon homself? (Glad nie 2, Minder as 2 keer per week 1, Meer as 2 keer per week 0)

3. Breek die persoon voorwerpe soos meubels en vensters? (Glad nie 2, Minder as 2 keer per maand 1 , meer as 2 keer per maand 0)

4. Ly die persoon aan woedebuie, skreeu, lag en vloek hy onbeheers? (Glad nie 2, Minder as 2 keer per week 1, Meer as 2 keer per week 0)

5. Bevredig die persoon gewoonlik sy seksuele drange in die openbaar, bv. masturbasie, ontbloot van geslagsdele? (Ja 0, Nee 2)

6. Is die persoon se seksuele gedrag sosiaal aanvaarbaar? (Ja 2, Nee 0)

7. Is daar ander psigiatriese afwykings aanwesig, bv, vervolgingswaan, hallusinasies, depressie, ens.? (Ja 0 , Nee 2)

8. Is pasiënt totaal spasties? (Ja 8 , Nee 0$)$

\section{KOMMUNIKASIE}

1. Kan die persoon die gesproke taal verstaan? (Ja 2, Nee 0)

2. Kan die persoon tekens en gebare verstaan? (Ja 2, Nee 0)

3. Kan die persoon 'n gesprek voer? (Verstaanbaar 2, Moeilik verstaanbaar 1, Glad nie 0)

4. Kan die persoon homself verstaanbaar maak deur tekens en gebare? ( Ja 2, Nee 0)

\section{WERKGEWOONTES}

1. Kan die persoon enige produktiewe werk verrig, bv. saalwerk, arbeidsterapie, ens.? (Ja 2, Gedeeltelik 1, Nee 0)

2. Kan die persoon sonder gedurige toesig werk? ( $\mathrm{Ja} 2$, Gedeeltelik 1, Nee 0)

3. Is die kwaliteit van die persoon se werk goed? (Ja 2, Gedeeltelik 1, Nee 0)

4. Is die persoon betroubaar in sy werk? ( $\mathrm{Ja} 2$, Gedeeltelik 1, Nee 0)

5. Stel die persoon belang in sy werk? ( $\mathrm{Ja} 2$, Gedeeltelik 1, Nee 0)

6. Is die persoon betyds vir werk? ( Ja 2, Gedeeltelik 1, Nee 0)

7. Het die persoon potensiaal om meer ingewikkelde werk te doen? (Ja 2, Gedeeltelik 1, Nee 0) 
1. Aanvaar die persoon opdragte van toesighouers? (Ja 2, Gedeeltelik 1, Nee 0)

2. Kommunikeer die persoon vryelik met ander persone? (Ja 2, Gedeeltelik 1, Nee 0)

3. Kan die persoon vriende maak met pasiënte/personeel? (Ja 2, Gedeeltelik 1, Nee 0)

4. Kan die persoon as lid van 'n groep werk of speel? (Ja 2, Gedeeltelik 1, Nee 0)

5. Kan die persoon gewoonlik sy beurt afwag? (Ja 2, Gedeeltelik 1, Nee 0)

6. Gee die persoon sy samewerking aan personeel? (Ja 2, Gedeeltelik 1, Nee 0)

7. Stel die persoon belang in nuwe aktiwiteite? (Ja 2, Gedeeltelik 1, Nee 0)

8. Kan die persoon leierskap aanvaar? (Ja 2, Gedeeltelik 1, Nee 0)

9. Verstaan die persoon dinge soos onselfsugtigheid, ywer, mededeelsaamheid, ens.? (Ja 2, Gedeeltelik 1, Nee 0)

\section{SLEUTEL VIR KLASSIFISERING}

\begin{tabular}{|rr|r|r|}
\hline \multicolumn{2}{|c|}{ KINDERS } & \multicolumn{2}{c|}{ VOLWASSENES } \\
\hline A & $56-70$ & A & $61-70$ \\
B & $40-55$ & B & $44-60$ \\
C & $19-39$ & C & $22-43$ \\
D & $0-18$ & D & $0-21$ \\
\hline
\end{tabular}

\section{ACTIVITY PROGRAMMES: “ANNEXURE”, 'B'}

\section{Category : Group D}

Take patient to toilet at the times you have already ascertained by observation that he most frequently wets and soils himself. Reward him with a chipnick and warm priase immediately he has used the toilet.

If he does not use the toilet, take him back without reprimanding him, and try again later.

\section{Walking}

Place a ladder on the floor.

Help patient to walk between the rungs of the ladder. Encourage them not to step on the rungs.

\section{Individual Activities}

Seat patients at a table.

Give each one a piece of play dough.

Teach them how to manipulate and cut the dought.

Encourage them to make forms.
Seat patients around a table.

Give each a set of blocks.

Show them how to make a tower.

Take their hands and help them by supporting their blocks until they become more competent.

\section{Musical Activities}

Play march or dance music on a tape recorder.

Encourage patients to move to music.

Stop music at intervals and tell the patients to sit down when the music stops.

Do not restart music until all patients are sitting.

\section{Encouraging Responses and Eye Contact}

Sit in front of patient and call his name.

Reward him with smiles and praise if he responds by looking at you.

If he does not respond take his head in your hands and move his face towards you as you call his name.

When this has succeeded several times, stand behind him and call his name, getting him to turn towards you.

\section{Category : Group C}

\section{Body Image}

Give each patient a cardboard doll which has its limbs and head cut off.

Encourage him to assemble it, using paper clips.

Seat patients in a circle and issue the following instructions:

"shake your head"

"close your eyes"

"clap your hands"

"move your toes"

"open and close your mouth"

"shrug your shoulders"

"bend your knees"

"stamp your feet"

\section{Marching to Music}

Teach patients to walk, skip, run, gallop, stop.

\section{Outings}

Take patients for a walk.

Get them to identify various objects.

Get them to collect items such as leaves, flowers, grasses and paste them on paper on their return. 


\section{GROSS MOTOR DEVELOPMENT}

\section{CONSULT}

\section{QUESTION}

Does the resident:

1. Move his/her limbs freely and frequently?

2. Move his/her head from side to side?

3. Raise his/her head when lying on (stomach) abdomen?

4. Hold his/her head upright when sitting?

5. Sit with support?

6. Roll from side to side?

7. Raise his/her body when lying on (stomach) abdomen?

8. Sit without support?

9. Move forward when lying on his/her abdomen?

10. Make crawling movements when supported?

11. Pull him/herself to a sitting position?

12. Crawl?

13. Pull him/herself to a standing position?

14. Stand without support?

15. Take a step forward when supported?

16. Walk with assistance?

17. Walk without assistance?

18. Judge distance (Eye-hand co-ordination)?

19. Judge distance (Eye-foot co-ordination)?

20. Have physical deformities to prevent active play?

21. Take part in active play?

22. Suffer from spasticity?

Werner \& Johnson:Task 35

Werner \& Johnson:Task 36

Werner \& Johnson:Task 37

Uys page $46-48$

Werner \& Johnson: Task 38

Uys Page 52

Uys Page 51

Uys Page 53

Uys Page 49

Uys Page 54-58

Werner \& Johson:Task 77

Werner \& Johnson:Tasks 78-79

Consult Physiotherapy Department for advice

Werner \& Johnson:Tasks 81-82

Finnie Pgs 32-67\&191-199

\section{EATING}

23. Make a sucking movement?

24. Transfer food from hand to mouth?

25. Transfer food from spoon to mouth?

26. Eat independently with a spoon?

27. Transfer food from fork to mouth?

28. Drink from a cup?

29. Drink from a glass?

30. Show appropriate table manners?

31. Suffer from spasticity?

Slides of Jonathan

\section{TOILET TRAINING}

32. Is the resident toilet trained?

Werner \& Johnson:Tasks 110-111

\& 113-118

\section{DRESSING}

Does the resident:

33. Pull up his pants?

34. Slide down his pants?

35. Take off shirt'?

36. Put on shirt?

37. Take off socks?

38. Put on socks?

39. Button his/her shirt? 


\section{PERCEPTION}

40. Put identical objects together?

41. Seperate grouped objects?

42. Do puzzles?

43. Match objects to objects?

44. Discriminate between objects

45. Match identical shapes, colours, pictures?

46. Match animals with sounds?

47. Match motor activities to hearing?

48. Measure quantity?

49. Recognise local sequences of events?

50. Arrange objects to duplicate a pattern?
Werner \& Johnson:Tasks 214-216

Werner \& Johnson:Task 217

Werner \& Johnson:Task 218

Werner \& Johnson:Task 219

Werner \& Johnson:Tasks 220-222

Werner \& Johnson:Tasks 223, 226, 227

Werner \& Johnson:Task 232

Werner \& Johnson:Task 233

Werner \& Johnson:Task 239

Werner \& Johnson:Task 240

Werner \& Johnson:Task 238

BIBLIOGRAPHY

1. Bensberg, G.J.: Teaching the Mentally Retarded. Southern Regional Educational Board. Georgia, 1965

2. Finne, N.R.: Handling the Young Cerebral Palsied Child at Home. E P Dulton \& Co. Inc., New York, 1975. 2nd Edition.

3. Henderson, V.:The Nature of Nursing MacMillan Co., New York, 1966.

4. Jay, P.: Report of the Commitree of Enquiry into Mental handicap Nursing and Care. Nursing Times, 22 March, 1979.

5. Johnson, V.M. \& R.A. Werner: A Step by Step learning Guide for Retarded Infants \& Children. Syracuse University Press. New York, 1975.

6. Uys, L.R.: Psigiatriese verpleging van die geestesvertraagde. P.J. de Villiers. Bloemfontein, 1977 